\title{
PEMBERDAYAAN MASYARAKAT DESA KRADENAN, PAPRINGAN, DAN PAGER, KECAMATAN KALIWUNGU, KABUPATEN SEMARANG DALAM PROGRAM HIDUP BERSIH DAN SEHAT
}

\author{
Ahmad Ahid Mudayana dan mahasiswa KKN \\ Universitas Ahmad Dahlan Yogyakarta \\ E-mail: nelyulfatullatifah@gmail.com
}

\begin{abstract}
Abstrak
Salah satu permasalahan yang ada di masyarakat Desa Kradenan, Papringan, dan Pager, Kecamatan Kaliwungu, Kabupaten Semarang adalah kurangnya kesadaran perilaku hidup bersih dan sehat di masyarakat. Maka program KKN UAD difokuskan pada kesehatan masyarakat. Program ini bertujuan untuk meningkatkan perilaku hidup bersih dan sehat menuju masyarakat yang sejahtera. Metode pelaksanaan program KKN meliputi : pendidikan masyarakat dan praktek langsung. Dampak dari kegiatan KKN ini adalah : 1) tercipta kesadaran masyarakat tentang pentingnya PHBS , 2) memberikan penyuluhan tentang bahayanya buang air besar di sungai 3) melakukan pemeriksaan jentik nyamuk dan pemberian obat Abate di masyarakat, 4) memberikan penyuluhan bahaya asap rokok di tempat umum, 5) mengajak masyarakat memeriksakan anaknya ke POSYANDU secara rutin.
\end{abstract}

Kata kunci: hidup bersih, pemberdayaan, sejahtera.

\begin{abstract}
One of the problems that exist in society Kradenan Village, Papringan, and Pager, Kaliwungu subdistrict, Semarang regency is the lack of awareness of clean and healthy living behavior in society. Then the UAD learning programs focused on public health. The program aims to improve living clean and healthy behavior towards a prosperous society. KKN program implementation methods include: education to people's practice. The impact of service learning activities are: 1) to create public awareness about the importance of health behavior, 2) providing information about the dangers of defecating in the river 3) examination of mosquito larvae and drug administration Abate community, 4) providing the dangers of secondhand smoke in public places, 5) invites people to POSYANDU children examined regularly.
\end{abstract}

Keywords: clean living, empowerment, peace.

\section{A. PENDAHULUAN}

Perilaku Hidup Bersih dan Sehat (PHBS) adalah semua perilaku kesehatan yang dilakukan atas kesadaran sehingga anggota keluarga atau keluarga dapat menolong dirinya sendiri di bidang kesehatan dan dapat berperan aktif dalam kegiatan - kegiatan kesehatan di masyarakat (Depkes RI, 2007). Pemberdayaan masyarakat harus dimulai dari rumah tangga atau keluarga, karena rumah tangga yang sehat merupakan asset atau modal pembangunan di masa depan yang perlu dijaga, ditingkatkan dan dilindungi kesehatannya. 
Beberapa anggota rumah tangga mempunyai masa rawan terkena penyakit menular dan penyakit tidak menular, oleh karena itu untuk mencegah penyakit tersebut, anggota rumah tangga perlu diberdayakan untuk melaksanakan PHBS (Depkes, 2013). Dengan demikian dalam pelaksanaan program PHBS di seluruh kawasan Indonesia juga menggunakan 10 indikator PHBS yang harus diperaktikan dirumah tangga karena dianggap mewakili atau dapat mencerminkan keseluruhan perilaku hidup bersih dan sehat, indikator tersebut adalah: 1) Pertolongan persalinan oleh tenaga kesehatan, 2) Bayi di beri ASI ekslusif, 3) Menimbang balita setiap bulan, 4) Ketersediaan air bersih, 5) Ketersediaan jamban sehat, 6) Memberantas jentik nyamuk, 7) Mencuci tangan dengan air bersih dan sabun, 8) Tidak merokok dalam rumah, 9) Melakukan aktifitas fisik setiap hari, 10) Makan buah dan sayur.

Kecamatan Kaliwungu merupakan salah satu kecamatan yang terletak di bagian selatan berbatasan langsung dengan Kabupaten Boyolali. Kecamtan Kaliwungu mempunyai 11 desa/kelurahan yaitu, Jetis, Kaliwungu, Kener, Kradenan, Mukiran, Pager, Papringan, Payungan, Regomulyo, Siwal, dan Udanwuh. Letak Kecamatan Kaliwungu yang strategis dengan tanah yang subur sehingga mayoritas pekerjaannya sebagai petani. Selain itu, sebagian kecil masyarakat Kecamatan Kaliwungu juga bekerja pada sektor lainnya seperti, peternakan dan perikanan.Desa Papringan, Kradenan, dan Pager termasuk desa yang berada di Kecamatan Kaliwungu Kabupaten Semarang.

Dari indikator di atas ada beberapa permasalahan yang ditemukan di Kecamatan Kaliwungu adalah : 1) Kurangnya pengetahuan prilaku hidup bersih dan sehat, 2) Masih banyak masyarakat yang melakukan buang air besar di sungai, 3) Kecamatan Kaliwungu termasuk daerah endemik DBD, 4) Belum bebas asap rokok ditempat umum, 5) Kurang aktifnya orang tua membawa anaknya ke POSYANDU untuk melakukan penimbangan rutin. Peran serta masyarakat dalam mengikuti penyuluhan PHBS membantu berhasilnya program PHBS di Kecamatan Kaliwungu tanpa adanya peran serta masyarakat semua program PHBS yang direncanakan akan sia-sia. Salah satu pendekatan masyarakat untuk dapat membantu program pemerintah dalam keberhasilan adalah membiasakan masyarakat pada tingkah laku yang sesuai dengan program PHBS yaitu merubah persepsi masyarakat terhadap kesehatan yang lebih baik.

Berdasarkan permasalahan tersebut, maka ditetapkan tujuan program KKN iniadalah memberdayakan masyarakat Kecamatan Kaliwungu dalam kepedulian terhadap kesehatan.

\section{B. METODE PELAKSANAAN}

Untuk mencapai tujuan yang diharapkan, program KKN di Kecamatan Kaliwungu dilakukan dengan pemberdayaan masyarakat melalui pendidikan masyarakatdan praktek langsung. Ringkasan metode pelaksanaan beserta jam kerja efektif mahasiswa (JKEM) tersaji pada tabel I. 
Tabel 1. Metode, Kegiatan, JKEM dan keterlibatan mahasiswa

\begin{tabular}{|c|c|c|c|c|}
\hline No & Metode & Kegiatan & JKEM & $\begin{array}{l}\text { Jumlah } \\
\text { mahasiswa } \\
\text { yang } \\
\text { terlibat }\end{array}$ \\
\hline \multirow[t]{4}{*}{1} & \multirow[t]{4}{*}{$\begin{array}{l}\text { Pendidikan } \\
\text { masyarakat }\end{array}$} & $\begin{array}{l}\text { Menyelenggarakan penyuluhan } \\
\text { perilaku hidup bersih dan sehat } \\
\text { (PHBS) untuk anak Taman Kanak- } \\
\text { kanak (TK) di TK At-Taqwa dan TK } \\
\text { Dharma Wanita Pager, sekolah dasar } \\
\text { (SD) dan Madrasah Ibtidaiyah (MI), } \\
\text { sekolah menengah kerjuruan (SMK) } \\
\text { dan Masyarakat }\end{array}$ & $\begin{array}{c}6 \times 100 \\
\text { menit }\end{array}$ & 8 \\
\hline & & $\begin{array}{l}\text { Menyelenggarakan penyuluhan buang } \\
\text { air besar di sungai untuk masyarakat } \\
\text { di kumpulan ibu PKK induk di desa } \\
\text { Pager }\end{array}$ & $\begin{array}{c}4 \times 100 \\
\text { menit }\end{array}$ & 8 \\
\hline & & $\begin{array}{l}\text { Menyelenggarakan penyuluhan } \\
\text { perilaku hidup bersih dan sehat } \\
\text { (PHBS) untuk lansia di Dusun Miri } \\
\text { dan Wonogiri di Desa Papringan }\end{array}$ & $\begin{array}{c}1 \times 150 \\
\text { menit }\end{array}$ & 9 \\
\hline & & $\begin{array}{l}\text { Menyelenggarakan penyuluhan } \\
\text { perilaku hidup bersih dan sehat } \\
\text { (PHBS) untuk masyarakat di Desa } \\
\text { Kradenan }\end{array}$ & $5 \times 200$ & 2 \\
\hline \multirow[t]{3}{*}{2} & \multirow[t]{3}{*}{ Praktek } & $\begin{array}{l}\text { Melaksanakan pemeriksaan jentik- } \\
\text { jentik nyamuk di Desa Pager } \\
\text { Kecamatan Kaliwungu, Semarang dan } \\
\text { pemberian Abate }\end{array}$ & $\begin{array}{c}4 \times 150 \\
\text { menit }\end{array}$ & 4 \\
\hline & & $\begin{array}{l}\text { Menyelenggarakan demonstrasi tujuh } \\
\text { langkah cuci tangan dan sikat gigi } \\
\text { yang baik dan benar untuk anak di TK } \\
\text { At-Taqwa dan TK Dharma Wanita } \\
\text { Pager }\end{array}$ & $\begin{array}{c}2 \times 100 \\
\text { menit }\end{array}$ & 8 \\
\hline & & $\begin{array}{l}\text { Penyelenggaraan pemeriksaan } \\
\text { kesehatan untuk Balita di Desa Pager }\end{array}$ & $\begin{array}{c}4 \times 100 \\
\text { menit }\end{array}$ & 3 \\
\hline
\end{tabular}

\section{HASIL, PEMBAHASAN DAN DAMPAK}

\section{Profil Desa.}

Desa Kradenan terdiri dari 9 Dusun, yaitu Dusun Kradenan I, Dusun Kradenan II , Dusun Kradenan III , Dusun Kradenan IV, Dusun Gender, Dusun Kedesen Kidul, Dusun Kedesen Lor, Dusun Kalikendang, dan Dusun Kebatan.Berdasarkan data monografi dari 
desa Kradenan diperoleh keterangan bahwa penduduk desa Kradenan per Februari 2017 adalah 4.801 jiwa, 2.374 laki-laki, 2.427 perempuan dan 1.113 jumlah kepala keluarga.

Desa Papringan memiliki sebanyak 13 dusun (Serut, Tanjung, Wonogiri, Mejing, Miri, Kadirojo, Kaporan, Pacean, Bestrikan, dan Langkap) dan 27 RT dengan jumlah Kepala Keluarga sebanyak 1095. Jumlah penduduk di Desa Papringan yaitu kurang lebih 3571 dengan laki-laki sebanyak 1749 dan perempuan 1822.

Desa Pager adalah salah satu desa yang berada di Kecamatan Kaliwungu Kabupaten Semarang, Indonesia. Luas wilayah Desa Pager sebesar 114,700 ha. Desa Pager merupakan Desa yang terletak $\pm 4 \mathrm{Km}$ dari kecamatan Kaliwungu dan jarak desa Pager ke kabupaten Semarang yaitu $56 \mathrm{~km}$. Jumlah penduduk desa Pager sebanyak 2.375 Jiwa dengan 618. Jumlah kepala keluarga yang terdiri dari laki-laki 1.189 Jiwa dan Perempuan 1.186 Jiwa.

\section{Gambaran Pelaksanaan}

Gambar aktivitas mahasiswa KKN UAD dan masyarakat Desa Kradenan dalam program PHBS pada gambar 1.

Gambar aktivitas mahasiswa KKN UAD dan masyarakat Desa Papringan dalam program PHBS pada gambar 2.

Gambar aktivitas mahasiswa KKN UAD dan masyarakat Desa Pager dalam program PHBS pada gambar 3.

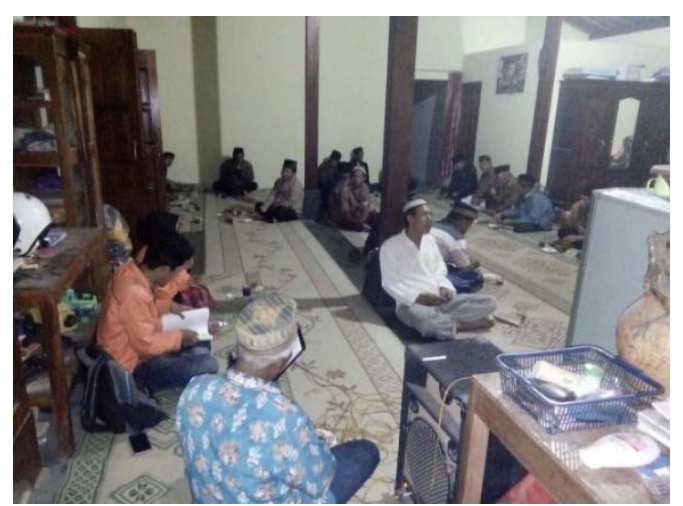

Gambar 1.1 Penyuluhan PHBS di Desa Kradenan 


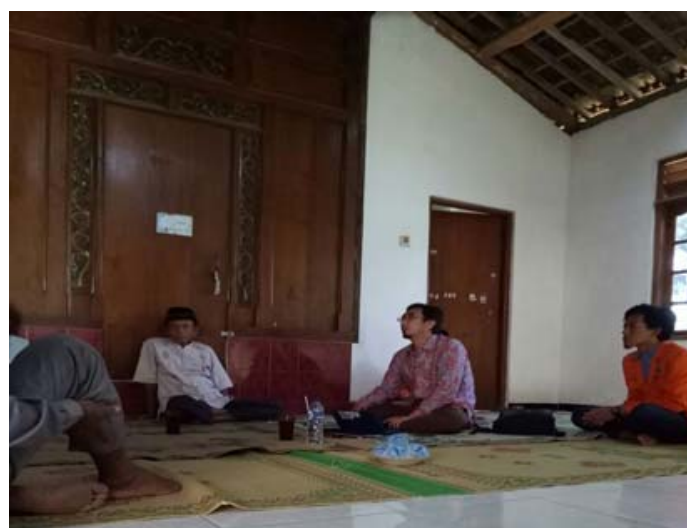

Gambar 2.1 Penyuluhan PHBS di Desa Papringan

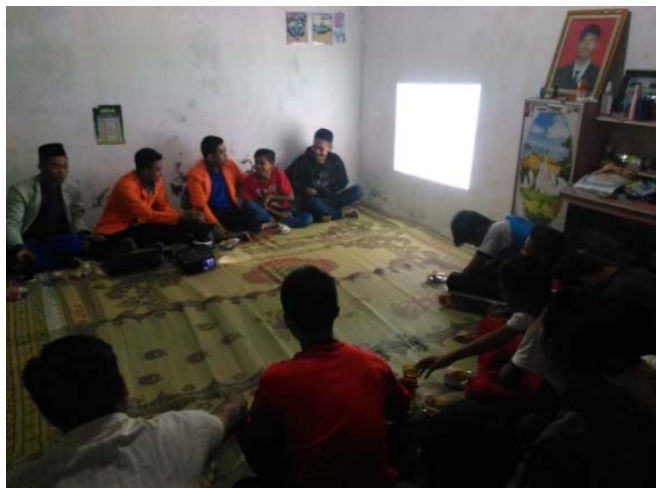

Gambar 3.1 Penyuluhan PHBS di masyarakat di Desa Pager

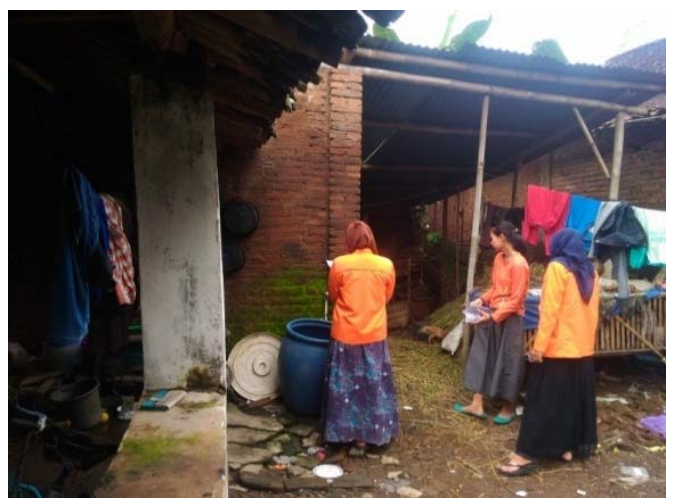

Gambar 3.3 Pemeriksaan jentik-jentik nyamuk di Desa Pager

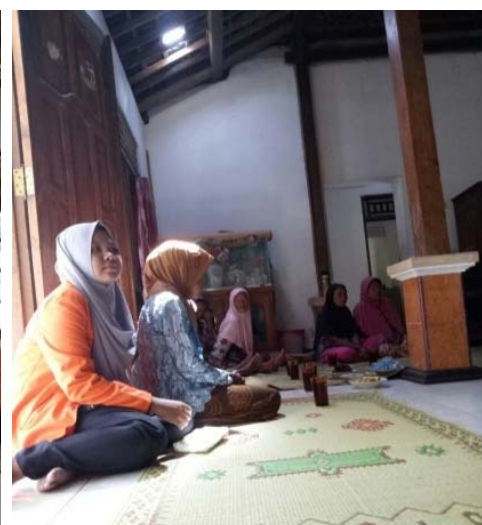

Gambar 2.2 Penyuluhan PHBS di Desa Papringan

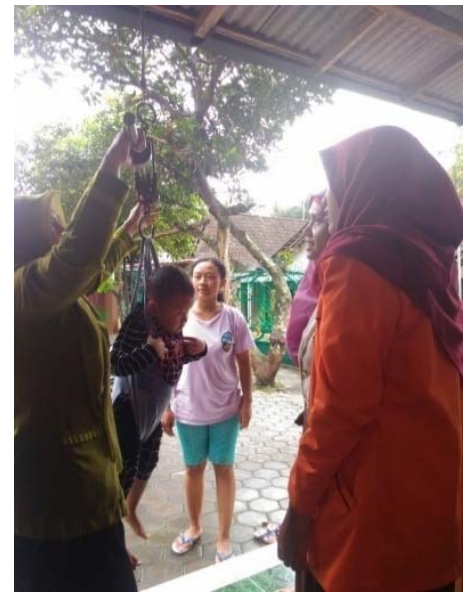

Gambar 3.2 Pemeriksaan kesehatan untuk Balita di Desa Pager

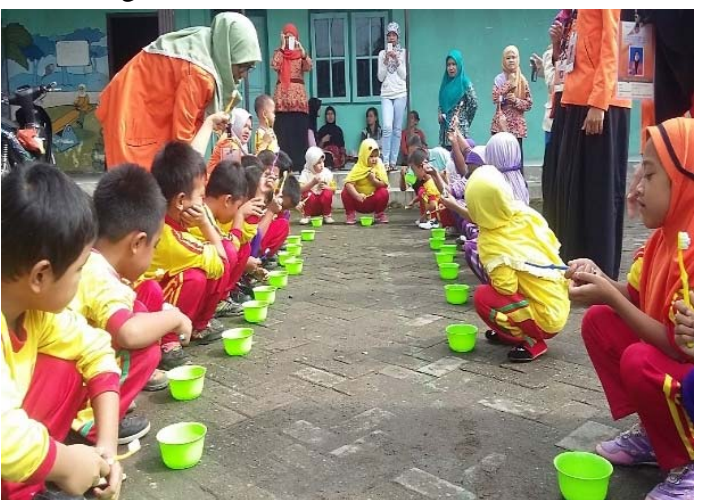

Gambar 3.4 Sikat gigi yang baik dan benar di Desa Pager

Dari gambar 1 terlihat program KKN di Desa Kradenan Kecamatan Kaliwungu dapat terlaksana dengan partisipasi masyarakat yang cukup tinggi dengan kata lain dapat memperdayakan masyarakat dalam program-program yang telah direncanakan. Dampak dari kegiatan KKN ini adalah tercipta kesadaran masyarakat tentang pentingnya PHBS di Desa Kradenan. 
Dari gambar 2 terlihat program KKN di Desa Papringan Kecamatan Kaliwungu dapat terlaksana dengan partisipasi masyarakat yang cukup tinggi dengan kata lain dapat memperdayakan masyarakat dalam program-program yang telah direncanakan. Dampak dari kegiatan KKN ini adalah tercipta kesadaran masyarakat tentang pentingnya PHBS di Desa Papringan.

Dari gambar 3 terlihat program KKN di Desa Pager Kecamatan Kaliwungu dapat terlaksana dengan partisipasi masyarakat yang cukup tinggi dengan kata lain dapat memperdayakan masyarakat dalam program-program yang telah direncanakan. Dampak dari kegiatan KKN ini adalah : 1) tercipta kesadaran masyarakat tentang pentingnya PHBS, 2) memberikan penyuluhan tentang bahayanya buang air besar di sungai, 3) melakukan pemeriksaan jentik nyamuk dan pemberian obat Abate dimasyarakat, 4) memberikan penyuluhan bahaya asap rokok di tempat umum, 5) mengajak masyarakat memeriksakan anaknya ke POSYANDU secara rutin.

Di tiga lokasi KKN dilaksanakan penyuluhan PHBS supaya pengetahuan masyarakat meningkat dan dapat mengetahui pentingnya berperilaku hidup bersih dan sehat. Pengetahuan dapat membentuk keyakinan seseorang sehingga ia dapat berperilaku dengan keyakinan tersebut, dengan kesehatan lingkungan yang baik diharapkan dapat meningkatkan kesadaran masyarakat tentang pentingnya menciptakan kondisi lingkungan yang sehatn, sehingga dapat memutuskan rantai penularan penyakit melalui lingkungan dan tidak dengan mudah tertular penyakit (Irawati dan Wahyuni, 2011).

Selain pengetahuan, pendidikan juga berpengaruh terhadap perilaku hidup bersih dan sehat di masyarakat. Pendidikan merupakan salah satu usaha pengorganisasian masyarakat untuk meningkatakan kesehatan karena tingkat pendidikan yang kurang dapat menyebabkan rendahnya tingkat kesadaran masyarakat akan kesehatan. Semakin baik tingkat pendidikan masyarakat maka akan mematangkan pemahaman tentang pengetahuan kesehatan dan penerapan PHBS dalam kehidupan sehari-hari. Mubarak (2007) menjelaskan bahwa pendidikan dapat menimbulkan perubahan pada diri seseorang, semakin tinggi pendidikan seseorang maka semakin mudah mereka menerima informasi tentang kesehatan. Sebaliknya, jika seseorang memiliki tingkat pendidikan rendah, maka akan menghambat perkembangan sesorang terhadap penerimaan informasi kesehatan dan nilai-nilai baru yang diperkenalkan.

Perilaku hidup bersih da sehat dapat dilihat dari perilaku masyarakat dalam penggunaan jamban. Masyarakat Desa Kadrenan, Papringan dan Pager masih belum menggunakan jamban sehat. Hasil studi Indonesia Sanitation Sector Development Program (ISSDP) tahun 2006, menunjukkan bahwa 47\% masyarakat masih berperilaku buang air besar ke sungai, sawah, kolam, kebun, dan tempat terbuka (Pardi, 2010). Hal ini sama seperti karakteristik masyarakat Kadrenan, Papringan dan Pager, yang mana masyarakat dari ketiga lokasi tersebut masyarakatnya masih ada yang buang air besar di sungai. Hal tersebut sama dengan hasil penelitian Gani (2013) yang menunjukkan bahwa PHBS masyarrakat Using dalam hal perilaku BAB belum berjalan secara optimal, karena total persentase masyarakat yang belum menggunakan jamban sehat sebesar $46 \%$. 


\section{KESIMPULAN}

PHBS di Rumah Tangga adalah upaya untuk memberdayakan anggota rumah tangga agar tahu, mau dan mampu melaksanakan perilaku hidup bersih dan sehat serta berperan aktif dalam gerakan kesehatan di masyarakat berjalan dengan baik.

\section{DAFTAR PUSTAKA}

Gani, H.A. 2013. Perilaku Hidup Bersih dan Sehat (PHBS) pada Masyarakat Using Di Kabupaten Banyuwangi. Jurnal IKESMA. Vol/No 9/2, Hal 147-158

Irawati, E. Wahyuni. 2011. Gambaran Karakteristik Keluarga Tentang Perilaku Hidup Bersih dan Sehat (PHBS) pada Tatanan Rumah Tangga di Desa Karangasem Wilayah Kerja Puskesmas Tanon II Sragen. Gaster. Vol.8 No.2, Hal 741-749

Mubarak,W.L. 2007. Promosi Kesehatan Sebuah Pengantar Proses Belajar-Mengajar dalam Pendidikan. Yogyakarta: Graha Ilmu.

Nurhajati, N. 2015. Perilaku Hidup Bersih dan Sehat (PHBS) Masyarakat Desa Samir Dalam Meningkatkan Kesehatan Masyarakat. Jurnal Kesehatan Masyarakat.

Pardi. 2010. Peningkatan Akses Sanitasi Melalui CLTS. Sanitasi Melalui CLTS. http://www.dinkesjatengprov.go.id/index.php?option=com_content\&view=article \&id=80\%3Apeningkatan-akses-sanitasi-melalui-clts\&catid=42\%3Apl\&lang=en 